\title{
DDX1 Gene
}

National Cancer Institute

\section{Source}

National Cancer Institute. DDX1 Gene. NCI Thesaurus. Code C24334.

This gene plays a role in the regulation of several processes involving the alteration of RNA secondary structure. 